\title{
Danuta Król
}

Uniwersytet Ekonomiczny we Wrocławiu

e-mail: depozyt1@wp.pl

\section{RACHUNKOWOŚĆ KREATYWNA \\ A RACHUNKOWOŚĆ AGRESYWNA}

\section{CREATIVE ACCOUNTING VS. AGGRESSIVE ACCOUNTING}

DOI: $10.15611 /$ nof.2015.2.01

JEL Classification: M4, M40, M41, M49

Streszczenie: Początek XXI wieku przyniósł kilkanaście spektakularnych przypadków, które przyczyniły się do utraty zaufania do przejrzystości i wiarygodności informacji prezentowanych w sprawozdaniach finansowych wielu jednostek gospodarczych. Oszustwa te zapoczątkowały zaciekłą dyskusję na temat rachunkowości kreatywnej, tak bowiem zaczęto określać wszelkie przypadki ujmowania operacji finansowych sprzecznie z zasadami księgowania. W polskiej literaturze przedmiotu nie ma zgody nie tylko co do samej definicji pojęcia „rachunkowość kreatywna”, ale również co do tego, czy ma ono pozytywne, czy też negatywne znaczenie. W artykule podjęto więc próbę zdefiniowania, uporządkowania i rozróżnienia pojęć „,rachunkowość kreatywna” i „rachunkowość agresywna”. Zostały przytoczone różnorodne ich definicje. Zaprezentowano też poglądy krajowych autorytetów w dziedzinie rachunkowości.

Słowa kluczowe: rachunkowość kreatywna, rachunkowość agresywna, oszustwa księgowe, wiarygodność sprawozdań finansowych.

Summary: The beginning of the XXI ${ }^{\text {st }}$ century witnessed a dozen spectacular cases which contributed to the loss of confidence in the clarity and reliability of information presented in financial statements of numerous economic entities. Those frauds started a heated debate on creative accounting, as in fact both in theory and in practice any instances of accounting operations contrary to the principles of accounting or with the actual state began to be named. In Polish literature there is disagreement not only about the very definition of "creative accounting", but also as to whether it has a positive or negative meaning. The article tried to define, organise and differentiate both concepts. Various definitions of creative and aggressive accounting were quoted and views and addressed aspects of the issues discussed by the national authorities in the field of accounting were presented.

Keywords: creative accounting, aggressive accounting, frauds, reliability of financial statements. 


\section{Wstęp}

Rachunkowość to system, którego głównym zadaniem jest prawdziwe i rzetelne, a co za tym idzie - wiarygodne, odzwierciedlenie rzeczywistości gospodarczej jednostki. Informacje na temat sytuacji majątkowej, finansowej i wyniku finansowego jednostki, tworzone w rachunkowości, a prezentowane w jej produkcie, którym jest sprawozdanie finansowe, stanowią i nadal będą stanowić podstawowe źródło danych do podejmowania decyzji przez różnorodnych odbiorców tego sprawozdania.

Niestety, początek XXI wieku przyniósł kilkanaście spektakularnych przypadków, które przyczyniły się do utraty zaufania do przejrzystości i wiarygodności informacji prezentowanych w sprawozdaniach finansowych wielu jednostek gospodarczych. Powodem tego było między innymi ujawnienie oszustwa finansowego, którego dopuściła się amerykańska firma Enron - gigant branży energetycznej. Firma ta, za pomocą sztuczek finansowych, ukrywała swoje straty i przedstawiała w pozytywnym świetle wyniki finansowe między innymi w celu przyciągnięcia potencjalnych inwestorów. Oszustwo finansowe firmy Enron doprowadziło do jej bankructwa w grudniu 2001 roku i zapoczątkowało zaciekłą dyskusję na temat rachunkowości kreatywnej. Z czasem kreatywną księgowością zaczęto nazywać wszelkie przypadki księgowania operacji finansowych przedsiębiorstwa sprzeczne z zasadami księgowania czy też ze stanem faktycznym.

Zarówno w teorii, jak i w praktyce gospodarczej rachunkowość kreatywna często jest utożsamiana (jednak niesłusznie) z rachunkowością agresywną. Kreatywna czy agresywna rachunkowość nie jest zjawiskiem nowym. W literaturze przedmiotu już czterdzieści lat temu pojawiły się prace, w których opisywano te zjawiska. Rachunkowość agresywną najczęściej wówczas nazywano „trikami” finansowymi. Jednakże rachunkowość kreatywna nie jest synonimem rachunkowości agresywnej. W artykule podjęto więc próbę zdefiniowania, uporządkowania i rozróżnienia obydwu pojęć. Realizując ten cel, posłużono się metodą analizy źródeł prawniczych i literatury przedmiotu, metodą analizy opisowej oraz metodą dedukcji. Zostały przytoczone różnorodne definicje rachunkowości kreatywnej i agresywnej. Zaprezentowano też poglądy i poruszono aspekty omawianych zagadnień w interpretacji krajowych autorytetów w dziedzinie rachunkowości.

\section{Pojęcie i przejawy rachunkowości kreatywnej}

Termin „rachunkowość kreatywna” od pewnego czasu robi w Polsce karierę i ma zdecydowanie negatywny wydźwięk. Sugeruje działania, które mają na celu ,upiększenie" sprawozdań finansowych w celu wprowadzenia w błąd ich czytelników i ukrycie prawdziwego obrazu firmy. Pozostaje to w sprzeczności ze słownikową definicją kreatywności, gdzie kreatywność to proces umysłowy pociągający za sobą powstawanie nowych idei, koncepcji lub nowych skojarzeń, powiązań z istniejący- 
mi już ideami i koncepcjami. Myślenie kreatywne to myślenie prowadzące do uzyskania oryginalnych i stosownych rozwiązań.

W polskiej literaturze przedmiotu nie ma zgody nie tylko co do samej definicji tego pojęcia, ale również co do tego, czy ma ono pozytywne czy też negatywne znaczenie $^{1}$. Biorąc jednak pod uwagę choćby znaczenie wyrazu „kreatywny”, co oznacza: „posiadający umiejętność tworzenia nowych jakości, operatywny, pomysłowy, pozwalający na dokonywanie istotnych zmian i ulepszeń, mający zdolność tworzenia"', wielu autorów dla oszustw księgowych proponuje wprowadzenie nowej nazwy, najczęściej ,agresywna księgowość”’.

Według P. Guta ${ }^{4}$ kreatywna księgowość (rachunkowość) to prowadzenie rejestracji, ewidencji, przetwarzanie i prezentacja zdarzeń gospodarczych przy zastosowaniu obowiązujących przepisów i właściwie interpretowanych zasad rachunkowości w sposób, który nie jest bezpośrednio w tych przepisach wskazany, a który jest wynikiem pomysłowego, twórczego i niestandardowego zastosowania tych przepisów i zasad. Zdaniem K. Gierusz ${ }^{5}$ menedżerowie, księgowi i zarządy stosują rozwiązania zgodne z prawem i rzeczywistością, chcąc ukazać firmę w jak najlepszym świetle. Dokonywane przez nich zmiany są subtelne i nieznaczne. W ten sposób rozumiana kreatywność dotyczy wszystkich przedsiębiorstw i nie ma nic wspólnego z łamaniem prawa, fałszowaniem sprawozdań finansowych, przestępstwami, oszustwami, defraudacją, malwersacją, które są przypisywane rachunkowości agresywnej. Z kolei D. Krzywda ${ }^{6}$ stawia tezę, że współczesna rachunkowość wymaga wręcz od księgowych kreatywności. Rachunkowość kreatywna - w rozumieniu pozytywnym - praktykowana jest przez większość firm, gdyż kreatywnie - zgodnie z ustawą o rachunkowości - to rzetelnie i jasno. A więc każda decyzja podjęta przez zarząd, a mająca na celu lepsze zaprezentowanie danych w sprawozdaniu finansowym i taki cel spełniająca jest elementem rachunkowości kreatywnej - pozytywnej rachunkowości kreatywnej. Ważną cechą tej strony rachunkowości kreatywnej jest to, że w sprawozdaniu finansowym fakt ten zostaje szczegółowo opisany, w ujęciu zarówno faktów (przyczyny), jak i efektów liczbowych (skutek). Jako przykład można podać tutaj zmianę stawek amortyzacyjnych, gdy zmiany mają uzasadniony charakter i w sprawozdaniu finansowym zostały odpowiednio opisane. Natomiast A. Wier-

${ }^{1}$ G. Gołębiowski, A. Tłaczała, Analiza finansowa $w$ teorii $i$ w praktyce, Difin, Warszawa 2009, s. 161

2 Praktyczny słownik współczesnej polszczyzny, H. Zgółkowska (red.), Wydawnictwo Kurpisz, Poznań 1998, za: P. Gut, Kreatywna księgowość a fatszowanie sprawozdań finansowych, Wydawnictwo C.H. Beck, Warszawa 2006, s. 10.

${ }^{3}$ E. Mączyńska. Nieuczciwych metod księgowych nie powinno się określać jako kreatywne. „Rzeczpospolita”, 9 sierpnia 2002.

${ }^{4}$ P. Gut, op. cit., s. 10-11.

${ }^{5}$ K. Gierusz, Pojęcia i przejawy rachunkowości kreatywnej i agresywnej, Accountica, nr 17/2010, s. 2, www.gierusz.com.pl.

${ }^{6}$ D. Krzywda, Rachunkowość finansowa, Fundacja Rozwoju Rachunkowości w Polsce, Warszawa 1999, s. 18. 
cińska ${ }^{7}$ uważa, że kreatywna rachunkowość w znaczeniu pozytywnym jest to umiejętne wykorzystanie praw wyboru polityki rachunkowości w ramach obowiązującego prawa $\mathrm{w}$ celu przedstawienia wizerunku przedsiębiorstwa zgodnie $\mathrm{z}$ założeniami postawionymi przez zarządzających.

Na podstawie tych definicji można przyjąć, że rachunkowość kreatywna, w pozytywnym znaczeniu, jest to świadomy wybór rozwiązań, jakie dopuszcza ustawa o rachunkowości, który ma na celu jak najbardziej obiektywne (tj. w sposób rzetelny i jasny) zaprezentowanie liczb w sprawozdaniu finansowym oraz ujawnienie tzw. transakcji pozabilansowych w informacji dodatkowej do sprawozdania, tak aby odbiorca sprawozdania finansowego miał jak najbardziej prawdziwy obraz sytuacji finansowej i majątkowej. Takie postrzeganie rachunkowości kreatywnej jest wskazane i pożądane - i absolutnie nie ma znamion nadużyć czy fałszowania danych. Bardziej w tym przypadku będziemy mówić o polityce rachunkowości niż rachunkowości kreatywnej. Kreatywna rachunkowość w pozytywnym rozumieniu kończy się jednak tam, gdzie łamane jest prawo. Zaczyna się wówczas tzw. księgowość agresywna - celowe działania, polegające na manipulacji danymi, fałszowaniu dokumentów, łamaniu zasad rachunkowości oraz tendencyjnym interpretowaniu przepisów. Działania te zawsze łamią jedną lub kilka zasad rachunkowości (np.: memoriału i współmierności, treści ekonomicznej czy kontynuacji działalności).

Współcześnie rozumiana rachunkowość to system informacyjny służący użytkownikom do podejmowania decyzji gospodarczych, zwłaszcza finansowych, oraz rozliczania kierownictwa $\mathrm{z}$ odpowiedzialnego i efektywnego zarządzania powierzonym majątkiem. Nowoczesna rachunkowość musi być zatem jakościowo lepsza od tradycyjnej, chociaż ustalenie kryterium oceny tego zjawiska nie jest proste. W związku z tym, że często zasady księgowania operacji gospodarczych nie są uregulowane wprost $\mathrm{w}$ przepisach prawa, $\mathrm{w}$ takiej sytuacji konieczne jest rozumienie intencji przepisów, a także umiejętność twórczego ich interpretowania. Interpretacja ta jednak powinna umożliwić zaewidencjonowanie operacji gospodarczych, a następnie zaprezentować w sprawozdaniu finansowym zgodne z ich rzeczywistą treścią ekonomiczną. Właściwie pojmowana kreatywność jest więc w rachunkowości niezbędna.

Na szczególną uwagę zasługuje podkreślenie znaczenia praktyki. Następuje daleko idąca intelektualizacja rachunkowości, która polega na tym, że praktycy rachunkowości muszą posługiwać się interdyscyplinarną wiedzą o przedsiębiorstwie, a więc znajomością kodeksu spółek handlowych, kodeksu cywilnego, procedur postępowania cywilnego i administracyjnego, prawa podatkowego i pochodnych tego prawa, znajomością systemów informacyjnych i informatycznych oraz rozległą wiedzą z rachunkowości. Ponadto muszą być przy tym otwarci na nowe idee, procesyi koncepcje, stosować nowoczesne rozwiązania, ale tylko takie, które są prawnie dozwolone.

${ }^{7}$ A. Wiercińska, Granica między kreatywna, agresywna i oszukańcza warunkowościa, [w:] Rachunkowość. Wybrane aspekty, „Prace i Materiały Wydziału Zarządzania Uniwersytetu Gdańskiego”, nr 2, Gdańsk 2008, s. 145. 


\section{Pojęcie i przejawy rachunkowości agresywnej}

Obok rachunkowości kreatywnej, w pozytywnym znaczeniu, w praktyce mamy do czynienia z niebezpiecznym procederem, określanym mianem rachunkowości agresywnej. W literaturze zarówno polskiej, jak i w zagranicznej spotyka się głosy, które utożsamiają rachunkowość kreatywną z manipulacjami rachunkowości agresywnej. Zdaniem W. Wąsowskiego ${ }^{8}$ kreatywna księgowość jest fałszowaniem sprawozdań finansowych, jest zabiegiem kosmetycznym, który kreuje obraz mający spełnić oczekiwania odbiorcy. W opinii E. Jakubczyk-Cały i K. Skibińskiego ${ }^{9}$ przesłanką do pojawienia się rachunkowości kreatywnej oraz oszustw księgowych są sprzeczne oczekiwania różnych grup interesariuszy: zarządu spółki, akcjonariuszy, pracowników i kontrahentów oraz organów podatkowych. Według K.H.M. Nasera ${ }^{10}$, jest to proces manipulowania danymi pochodzącymi z rachunkowości, przy wykorzystaniu luk w zasadach rachunkowości. Z kolei G.K. Świderska ${ }^{11}$ definiuje agresywną rachunkowość jako świadome, zamierzone i celowe prowadzenie rejestracji, ewidencji, przetwarzanie i prezentację zdarzeń gospodarczych w sposób sprzeczny z przepisami lub przy niewłaściwie i tendencyjnie interpretowanych przepisach oraz zasadach rachunkowości, które może zaszkodzić użytkownikom informacji księgowych przez przedstawienie innej (lepszej lub gorszej) niż rzeczywista sytuacji ekonomicznej jednostki.

Dla zdefiniowania kreatywnej księgowości bardzo istotne są stwierdzenia dotyczące nieprawidłowości księgowych, zawarte w Międzynarodowych Standardach Rewizji Finansowej (MSRF) nr 240 12 , które są, a przynajmniej powinny być, swego rodzaju wademekum każdego rachunkowca. Co prawda w MSRF nie używa się pojęć „kreatywna księgowość” i ,agresywna księgowość”, jednak występują w nich pojęcia „błąd (księgowy)” i „oszustwo (księgowe)”. Zgodnie z MSRF 240 oszustwo księgowe dotyczy działań pracowników, członków kierownictwa, organów nadzoru, osób trzecich powodujących fałszywe przedstawienie faktów w sprawozdaniach finansowych, służących uzyskaniu niezgodnych z prawem korzyści.

Na podstawie wyżej prezentowanych poglądów rachunkowość agresywną można zdefiniować jako świadome działanie, które prowadzi do nierzetelnego przedsta-

${ }^{8}$ W. Wąsowski, Kreatywna rachunkowość. Fatszowanie sprawozdań finansowych, Difin, Warszawa 2010 , s. 14.

${ }^{9}$ E. Jakubczyk-Cały, K. Skibiński, Nieprawidłowości w sprawozdaniach finansowych jednostek, Monitor Rachunkowości i Finansów, nr 6/2001, s. 25.

${ }^{10}$ K.H.M. Naser, Creative Financial Accounting, Prentice Hall International, London 1993, s. 59.

${ }^{11}$ G.K. Świderska, Zmiany w prawie gospodarczym a kreatywna rachunkowość, [w:] Rewizja finansowa a zmiany w prawie gospodarczym, Krajowa Izba Biegłych Rewidentów, Warszawa 2003, s. 100.

${ }_{12}$ Międzynarodowe Standardy Rewizji Finansowej, Standard nr 240: Odpowiedzialność biegłego rewidenta za uwzględnianie podczas badania sprawozdania finansowego możliwości wystąpienia oszustw i błędów, 2001, s. 97. 
wienia sytuacji majątkowej i finansowej jednostki, a więc niezgodnego $\mathrm{z}$ ustawą o rachunkowości, której artykuł 4 stanowi, że ,jednostki obowiązane są stosować przyjęte zasady (politykę) rachunkowości, rzetelnie i jasno przedstawiając sytuację majątkową i finansową oraz wynik finansowy" "'3 Jest to więc takie działanie, które ma na celu ukształtowanie u czytelników sprawozdania finansowego z góry założonego pozytywnego wizerunku jednostki. Innymi słowy, najpierw określa się dane, jakie powinno zawierać sprawozdanie finansowe, a dopiero później dobiera się odpowiednie zasady rachunkowości, aby osiągnąć założony wynik. Należy podkreślić, że agresywna księgowość ma charakter destrukcyjny z punktu widzenia przeprowadzanych analiz finansowych. W takich przypadkach analiza finansowa staje się narzędziem bezużytecznym, gdyż nie odzwierciedla rzeczywistych wyników osiągniętych przez jednostkę gospodarczą.

Oszustwa księgowe nie są zjawiskiem nowym. Nigdy jednak nie stanowiły takiego zagrożenia stabilności światowego systemu finansowego jak obecnie ${ }^{14}$. Wynika to z postępującej liberalizacji przepływu kapitałów i siły roboczej między różnymi regionami i krajami, wskutek czego wzrósł stopień niepewności co do przetrwania na rynku w warunkach zaostrzającej się konkurencji i gwałtownych zmian zachodzących we wszystkich sferach życia społecznego i gospodarczego ${ }^{15}$. Oszustwo jest rozmyślnym działaniem, podejmowanym w celu zapewnienia sobie nieuczciwych lub bezprawnych korzyści. Przykładami takich oszustw są oszustwa wielkich, amerykańskich firm WorldCom Inc oraz Enron Corp. W Polsce również zanotowano przypadki wykorzystania agresywnej księgowości. Takie sytuacje dotyczyły m.in. Spółki Elektrim, Animex, banków PKO SA i BPH ${ }^{16}$.

Oszustwa księgowe mogą dotyczyć praktycznie każdej z pozycji sprawozdania finansowego, a najczęściej polegają na:

- manipulacji, zafałszowaniu lub zmianie danych/dokumentów,

- wyłączeniu lub pominięciu w zapisach księgowych lub dokumentach skutków transakcji,

- rejestrowaniu transakcji fikcyjnych,

- zawyżaniu cen zakupów lub nieuzasadnionych zakupach,

- sprzedaży i udzielaniu kredytu kupieckiego nierzetelnym kontrahentom,

- udzielaniu pożyczek, gwarancji oraz zakupie obligacji od niepewnych lub powiązanych podmiotów,

- wyprzedaży majątku po zaniżonych cenach (np. do spółek zależnych),

- zawłaszczaniu majątku,

${ }^{13}$ Ustawa z 29 września 1994 o rachunkowości, (tj. DzU z 2013 r., poz. 330 z późn. zm).

${ }_{14}$ M. Tokarski, Sprawozdanie finansowe - niedoskonate źródto informacji o sytuacji finansowej przedsiębiorstwa, Przedsiębiorczość - Edukacja 2009, s. 176.

${ }_{15}$ M. Kutera, A. Hołda, S. Surdykowska, Oszustwa księgowe - teoria i praktyka, Difin, Warszawa 2006, s. 9.

${ }^{16}$ Szerzej na ten temat A. Andrzejewski, Rachunkowość a ujawnianie informacji przez spótki giełdowe, PWN, Warszawa 2002, s. 132-133. 
- niewłaściwym stosowaniu polityk rachunkowości i umieszczaniu nieprawidłowych danych w sprawozdaniach finansowych.

Główną przyczyną stosowania rachunkowości agresywnej jest pogoń za zyskiem, ponieważ świadome zniekształcanie informacji o sytuacji majątkowej, finansowej i dochodowej jednostki najczęściej służy osiągnięciu szeroko pojętych korzyści majątkowych. W tym celu zarządzający wprowadzają mniejsze lub większe modyfikacje sprawozdań finansowych, by „upiększyć” wyniki firmy. Inną przyczyną jest próba uniknięcia przez kadrę kierowniczą odpowiedzialności za nieprawidłowości w zarządzaniu jednostką. Chcą w ten sposób uniknąć negatywnych skutków kontroli ze strony akcjonariuszy, ukryć ryzyko finansowe, poprawić zdolność kredytową lub wycenę spółki - na przykład przed planowanym wejściem na giełdę lub przed transakcją sprzedaży firmy. Nadużycia księgowe mogą też wynikać z inicjatywy szeregowych pracowników, usiłujących w mniej lub bardziej finezyjny sposób ukryć swe działania na szkodę firmy. Warunkiem sprzyjającym rachunkowości kreatywnej w negatywnym tego słowa znaczeniu jest presja sprostania oczekiwaniom rynku lub wymaganiom właścicieli i wierzycieli ${ }^{17}$. Ogłaszanie wyników znacznie poniżej oczekiwanego poziomu może spowodować wycofanie się obecnych inwestorów lub wstrzymanie napływu nowych. Ponadto jeżeli firma w danym roku wykaże wyjątkowo dobre wyniki, powstanie presja, aby w latach kolejnych wyniki kształtowały się na równie wysokim poziomie. Presja inwestorów i wierzycieli może być wystarczająco silna, by zarząd uległ pokusie kształtowania danych.

Rachunkowości kreatywnej używają wszystkie bez wyjątku zarządy firm, które chcą tak zaprezentować dane finansowe, aby przedstawić firmę w jak najlepszym świetle. Sprawozdania finansowe i inna dokumentacja zawsze tworzą umiejętne zespolenie interesów jednostek z wymogami prawnymi i oczekiwaniami adresatów (akcjonariuszy, urzędów skarbowych, banków kredytujących). W odróżnieniu od rachunkowości kreatywnej, dzięki której firma może, nie naruszając reguł prawa, np. zmniejszyć ciężary podatkowe - w przypadku rachunkowości agresywnej obciążenia podatkowe przedsiębiorstw często rosną, a negatywne tego następstwa ponoszą właściciele.

\section{Stanowisko autora wobec rachunkowości kreatywnej i rachunkowości agresywnej}

Sprawozdania finansowe pełnią istotną funkcję w ocenie wyników działalności przedsiębiorstwa $\mathrm{z}$ wykorzystaniem analizy finansowej. W procesie decyzyjnym współczesnego przedsiębiorstwa analiza finansowa przeprowadzana z wykorzystaniem sprawozdań finansowych stanowi podstawę systemu informacji niezbędnego do prawidłowego przebiegu procesu zarządzania. Dysponowanie określonym systemem informacji sprawozdawczości finansowej pozwala na wczesne przygotowanie

17 Sprawozdanie finansowe bez tajemnic, G.K. Świderska (red.), Difin, Warszawa 2006, s. XVII. 
jednostki do zmian otoczenia, identyfikację ryzyka, wybór właściwych form zabezpieczenia się przed jego skutkami oraz konstrukcję właściwych scenariuszy sytuacyjnych.

Sprawozdanie finansowe jest końcowym produktem procesu przetwarzania informacji w systemie rachunkowości. Stanowi główne źródło informacji o sytuacji jednostki. Zakres sprawozdania finansowego jest określony w ustawie o rachunkowości. W celu zachowania przejrzystości, rzetelności i wiarygodności sprawozdań finansowych powinny być one sporządzane według określonych zasad. Istnieje wiele koncepcji ich interpretacji i prezentacji. $Z$ treści tych norm można jednak wyprowadzić pewne zasady nadrzędne, które są powszechnie uznawane i honorowane. Do najważniejszych zasad należą:

a) zasada memoriałowa - nakłada na jednostki gospodarcze obowiązek ujmowania w danych okresach obrachunkowych operacji gospodarczych, które w nich wystąpiły, bez względu na to, czy rozrachunki powstałe w związku z nimi zostały w tych okresach uregulowane;

b) zasada kontynuacji działania - wprowadza domniemanie, że jednostka gospodarcza będzie w dającej się przewidzieć przyszłości kontynuowała swoją działalność w niezmienionym istotnie zakresie;

c) zasada wiernego obrazu - zobowiązuje jednostki gospodarcze do odzwierciedlania w ich rachunkowości realnej sytuacji majątkowej i finansowej z uwzględnieniem różnych warunków zewnętrznych, takich jak: stopa inflacji, wahania kursów walut, wahania giełdowe, sytuacja na rynku;

d) zasada ostrożności (zasada ostrożnej wyceny) - dotyczy takiej wyceny majątku i kapitału jednostki gospodarczej, aby pomiar ten nie spowodował zniekształcenia wyniku finansowego;

e) zasada periodyzacji - ujmowanie działalności jednostek gospodarczych w wyznaczonych odcinkach czasu, które ograniczone są umownymi datami (okresy obrachunkowe);

f) zasada podmiotowości - polega na prowadzeniu rachunkowości w jednostkach gospodarczych, czyli podmiotach, które są wyodrębnione pod względem majątkowym, organizacyjnym i prawnym.

Często się jednak zdarza, że zasady księgowania operacji gospodarczych nie są uregulowane wprost $\mathrm{w}$ przepisach prawa. W takiej sytuacji konieczne jest rozumienie intencji przepisów, a także umiejętność twórczego ich interpretowania tak, aby zaewidencjonować, a następnie zaprezentować daną operację gospodarczą zgodnie z jej rzeczywistą treścią ekonomiczną. Właściwie pojmowana kreatywność jest w rachunkowości niezbędna, powinna jednak mieścić się w pewnych granicach i nie mieć nic wspólnego z manipulacjami w księgach rachunkowych i sprawozdaniach finansowych ${ }^{18}$.

18 K. Schneider, Błędy i oszustwa w dokumentach finansowo-księgowych, PWE, Warszawa 2007, s. 232. 
Określenia „kreatywna księgowość” często używa się błędnie, w zasadzie wyłącznie w negatywnym kontekście, podczas gdy rozwiązanie kreatywne może być pozytywne, zgodne z prawem i korzystne dla odbiorców sprawozdania finansowego. Istnieje bardzo wiele przepisów regulujących księgowość. Mają one na celu zapewnienie, że transakcje będą przedstawiane zgodnie z ich treścią ekonomiczną. Ujawnienie w sprawozdawczości finansowej istotnej, kompletnej i wiarygodnej informacji, na podstawie której użytkownicy tego sprawozdania mogą podejmować właściwe decyzje ekonomiczne, zależy od sposobu stosowania prawa oraz dorobku teorii i praktyki rachunkowości przez osoby zajmujące się rachunkowością. Rachunkowość kreatywna oznacza bowiem wykorzystanie przez sporządzających sprawozdania finansowe zakresu wolności, który wynika z braku odpowiednich standardów i ścisłych reguł, stanowiących podstawę podejmowania decyzji w ramach czterech głównych etapów procesu tworzenia informacji prezentowanych w sprawozdaniach finansowych przedsiębiorstw, tzn.: uznawania (problem dotyczy w szczególności rezerw i zobowiązań oraz kwalifikacji przychodów), wyceny składników aktywów i zobowiązań, prezentacji pozycji w sprawozdaniu finansowym oraz ujawniania informacji w sprawozdaniu finansowym.

Podsumowując, należy stwierdzić, że rachunkowość kreatywna w ciągle zmieniającym się i bardziej skomplikowanym otoczeniu ekonomiczno-prawnym będzie nabierała coraz większego znaczenia, ponieważ procesy legislacyjne nie nadążają za rzeczywistością gospodarczą. Mimo to, kreatywności nie należy się obawiać, pod warunkiem jednak, że przyświeca jej pokazanie w sprawozdaniu finansowym realnego obrazu przedsiębiorstwa.

Rachunkowość agresywna natomiast, która przecież polega na świadomym, zamierzonym i celowym prowadzeniu rejestracji, ewidencji, przetwarzaniu i prezentacji zdarzeń gospodarczych w sposób sprzeczny z przepisami lub przy niewłaściwym i tendencyjnym interpretowaniu przepisów oraz zasad rachunkowości, może negatywnie wpłynąć na wizerunek jednostki gospodarczej. W razie ujawnienia takich praktyk potencjalni inwestorzy mogą się od tych jednostek odwrócić. Takie przedsiębiorstwa są bowiem uważane za mało wiarygodne i niepewne. Niestety, nie ma w pełni skutecznych rozwiązań przeciwdziałających manipulacjom księgowym. Dlatego podstawową funkcją standardów i innych regulacji rachunkowości powinno być dostarczenie wystarczającej pewności, że system księgowości nie wymknie się spod kontroli, umożliwiając m.in. wczesne rozpoznanie zagrożeń dla działalności, przypadków stosowania rachunkowości agresywnej i tworzenie systemu wczesnego ostrzegania inwestorów. Rozstrzygająca jest jednak etyka księgowych, audytorów, zarządów i członków rad nadzorczych ${ }^{19}$. Przy ich doborze jest zatem istotne staranne uwzględnianie nie tylko kwalifikacji zawodowych, ale i predyspozycji osobowo-

19 Szerzej na ten temat zob. K. Sawicki, Obiektywizm i niezależność biegłych rewidentów i księgowych wedlug kodeksów etyki zawodowej i przepisów prawa, Zeszyty Naukowe Uniwersytetu Szczecińskiego nr 765, Finanse, Rynki Finansowe, Ubezpieczenia, 2013, nr 61, t. 2, s. 581-594. 
ściowych. Bez profesjonalizmu opartego na etyce zawodowej rachunkowość bowiem nie gwarantuje wiarygodności informacji, jako że dotychczas żadne regulacje międzynarodowe lub krajowe nie obejmują wszystkich możliwych przypadków z życia gospodarczego.

\section{Zakończenie}

Współcześnie rozumiana rachunkowość to system informacyjny służący użytkownikom do podejmowania decyzji gospodarczych, zwłaszcza finansowych, oraz rozliczania kierownictwa $\mathrm{z}$ odpowiedzialnego i efektywnego zarządzania powierzonym majątkiem. Nowoczesna rachunkowość musi być zatem jakościowo lepsza od tradycyjnej, chociaż ustalenie kryterium oceny tego zjawiska nie jest proste. W związku z tym, że często zasady księgowania operacji gospodarczych nie są uregulowane wprost w przepisach prawa, konieczne jest rozumienie intencji przepisów, a także umiejętność twórczego ich interpretowania. Interpretacja ta jednak powinna umożliwić zaewidencjonowanie operacji gospodarczych. Właściwie pojmowana kreatywność jest więc w rachunkowości niezbędna.

Rachunkowość kreatywna, w pozytywnym znaczeniu, to świadomy wybór rozwiązań dopuszczonych przez ustawę o rachunkowości, który ma na celu jak najbardziej obiektywne (tj. w sposób rzetelny i jasny) zaprezentowanie liczb w sprawozdaniu finansowym oraz ujawnienie tzw. transakcji pozabilansowych $w$ informacji dodatkowej do sprawozdania tak, aby odbiorca sprawozdania finansowego miał jak najbardziej prawdziwy obraz sytuacji finansowej i majątkowej. Jest to podejście do rachunkowości, które dostrzega zmiany zachodzące w podmiocie i reaguje na nie, co przekłada się na odpowiednią prezentację danych w sprawozdaniach finansowych. Takie postrzeganie rachunkowości kreatywnej jest wskazane i pożądane i absolutnie nie ma znamion nadużyć czy fałszowania danych. Zatem rachunkowość kreatywna to rachunkowość twórcza, czyli takie prowadzenie ksiąg rachunkowych i sporządzanie sprawozdań finansowych, które w rzeczywisty sposób prezentuje podmiot w układzie odpowiadającym jego specyfice.

Z kolei rachunkowość agresywna czy też oszustwo księgowe to świadome działanie, które prowadzi do nierzetelnego przedstawienia sytuacji majątkowej i finansowej jednostki, a więc niezgodnego $\mathrm{z}$ ustawą o rachunkowości. Jest to działanie, które za pomocą różnych sztuczek księgowych, naruszających prawo bądź dopuszczalnych przez prawo, ale będących na krawędzi legalności, ma na celu ukształtowanie u czytelników sprawozdania finansowego z góry założonego pozytywnego wizerunku jednostki zgodnie z zamierzeniem osób zarządzających. Oszustwo księgowe jest rozmyślnym działaniem, podejmowanym w celu zapewnienia sobie nieuczciwych lub bezprawnych korzyści.

Określenia „kreatywna księgowość” często używa się błędnie w zasadzie wyłącznie w negatywnym kontekście, podczas gdy rozwiązanie kreatywne może być pozytywne, zgodne z prawem i korzystne dla odbiorców sprawozdania finansowego. 
Niedopuszczalne jest zatem używanie zamiennie pojęć typu: rachunkowość kreatywna, rachunkowość agresywna, oszustwo, fałszerstwo czy przestępstwo, ponieważ granica między tymi pojęciami jest wyraźnie widoczna.

\section{Literatura}

Andrzejewski M., Rachunkowość a ujawnianie informacji przez spółki giełdowe, PWN, Warszawa 2002.

Gierusz K., Pojęcia i przejawy rachunkowości kreatywnej i agresywnej, Accountica, nr 17/2010, www. gierusz.com.pl.

Gołębiowski G., Tłaczała A., Analiza finansowa w teorii i w praktyce, Difin, Warszawa 2009.

Gut P., Kreatywna księgowość a fatszowanie sprawozdań finansowych, Wydawnictwo C.H. Beck, 2006.

Hołda A., Nowak Warszawa W., Oszustwa w systemie rachunkowości a ewolucja procedur badania sprawozdań finansowych, „Zeszyty Teoretyczne Rachunkowości”, t. 13(69), Warszawa 2003.

Jakubczyk-Cały E., Skibiński K., Nieprawidłowości w sprawozdaniach finansowych jednostek, „Monitor Rachunkowości i Finansów", nr 6/2001.

Krzywda D., Rachunkowość finansowa, Fundacja Rozwoju Rachunkowości w Polsce, Warszawa 1999.

Kutera M., Hołda A., Surdykowska S., Oszustwa księgowe - teoria i praktyka, Difin, Warszawa 2006.

Mączyńska E., Nieuczciwych metod księgowych nie powinno się określać jako kreatywne, „Rzeczpospolita", 9 sierpnia 2002.

Międzynarodowe Standardy Rewizji Finansowej, Standard nr 240: Odpowiedzialność biegłego rewidenta za uwzględnianie podczas badania sprawozdania finansowego możliwości wystąpienia oszustw i błędów, 2001.

Naser K.H.M., Creative Financial Accounting, Prentice Hall International, London 1993.

Praktyczny słownik współczesnej polszczyzny, H. Zgółkowska (red.), Wydawnictwo Kurpisz, Poznań 1998.

Sawicki K., Obiektywizm i niezależność biegtych rewidentów i księgowych wedlug kodeksów etyki zawodowej i przepisów prawa, Zeszyty Naukowe Uniwersytetu Szczecińskiego nr 765, Finanse, Rynki Finansowe, Ubezpieczenia, 2013, nr 61, t. 2.

Schneider K., Btędy i oszustwa w dokumentach finansowo-księgowych, PWE, Warszawa 2007.

Sprawozdanie finansowe bez tajemnic, G.K. Świderska (red.), Difin, Warszawa 2006.

Świderska G.K., Zmiany w prawie gospodarczym a kreatywna rachunkowość, [w:] Rewizja finansowa a zmiany w prawie gospodarczym, Krajowa Izba Biegłych Rewidentów, Warszawa 2003.

Tokarski M., Sprawozdanie finansowe-niedoskonate źródto informacji o sytuacji finansowej przedsiębiorstwa, Przedsiębiorczość - Edukacja, Kraków 2009.

Ustawa z dnia 29 września 1994 roku o rachunkowości, tj. Dz.U. 2013, poz. 330 z późn. zm.

Wąsowski W., Kreatywna rachunkowość. Fatszowanie sprawozdań finansowych, Difin, Warszawa 2010.

Wiercińska A., Granica między kreatywna, agresywna i oszukańczq warunkowościa, [w:] Rachunkowość. Wybrane aspekty, „Prace i Materiały Wydziału Zarządzania Uniwersytetu Gdańskiego”, nr 2, Gdańsk 2008. 